\section{Matjaz Celarc}

University of Ljubljana (Slovenia)

Matjaz.Celarc@teof.uni-lj.si

ORCID 0000-0001-9586-6955

DOI: http://dx.doi.org/10.12775/BPTh.2021.007
Biblica

et

Patristica

Thoruniensia

14 (2021) 2: 145-163

ISSN (print) 1689-5150

ISSN (online) 2450-7059

\title{
Narrative summaries in Acts of the Apostles. Reading of the first summary account (2:42-47)
}

\begin{abstract}
The article presents the reading of the first summary narrative account in the Acts of the Apostles by adopting Point of View Analysis together with the Intertextual Reading of the Isaianic prophecies. The articles thus shed light on the nascent Christian community that enjoys God's blessing through welcoming homes and table-fellowship among the community members.
\end{abstract}

Keywords: point of view analysis; intertextual reading; Isaianic New Exodus; nascent community.

\section{Introduction}

Biblical reading has always been a mirror of the Church's liturgical and daily life. However, the summary narrative accounts in the Acts of the Apostles (2:42-47; $4: 32-35 ; 5: 12-16)^{1}$ have a unique place in this regard, as they depict the life of the nascent Church. This article reads the description of the community's life, as the members dedicate themselves to the unity of teaching, table-fellowship, and prayers, as portrayed in the first summary account.

1 Along with the three major summary narrative accounts $(2: 42-47 ; 4: 32-35 ; 5: 12-16)$, the narrative of Acts displays also seven shorter, minor summary statements $(1: 14 ; 6: 7 ; 9: 31$; $12: 24 ; 19: 20 ; 28: 30-31)$ that divide the narrative into six narrative panels and show the constant growth of the word of God. Moreover, there are also numerical summaries $(2: 41 ; 4: 4$; $5: 14 ; 6: 1.7 ; 9: 31 ; 11: 21.24 ; 14: 1 ; 19: 20)$ that are membered in the previous two groups; however, they focus on the numerical growth of the community. (Fitzmyer 2003, 66-67) 


\section{Prerequisites for interpretation}

\subsection{Immediate context}

As the summaries are supported by the second level of the narrative, they offer subtle interplay of echoes and allusion, that are easily perceived through the cumulative elements found in their narrative context.

Thus, in Acts 2, Peter edits Joel's promise using Isaiah in order to establish (1) an eschatological, (2) a personal and (3) a universal link.

(1) To this end Peter twice underscores the eschatological tone of the prophecy by introducing a redactional change, shifting from "afterward [those

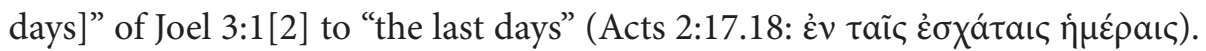
This eschatological twist, i.e., "latter days" evokes Isaiah's view, indicating that the Lord's Law and his word of judgment are valid for both Israel and all the

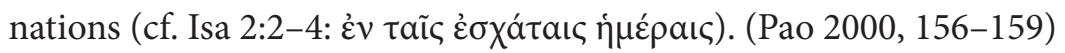

(2) The Spirit of prophecy is bestowed upon the servants, as Joel envisions

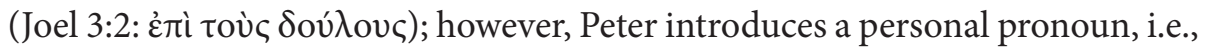
indicating God's personal relationship towards the servant, as seen by Isaiah

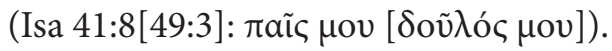

(3) Moreover, the gift of the Spirit bestowed "upon every flesh" (Joel 3:1; Acts 2:17) suggests a universal dimension evoking elements of the Isaianic NE:

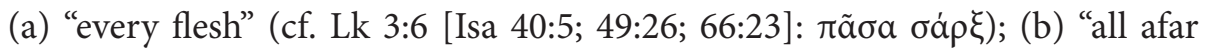

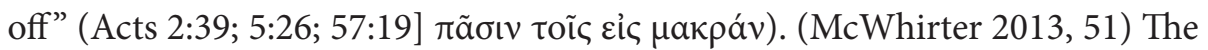
universal dimension (c) "ends of the earth," is further confirmed at two compo-

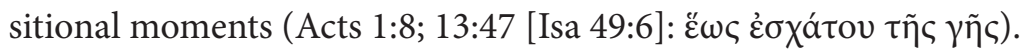

\begin{tabular}{|c|c|}
\hline 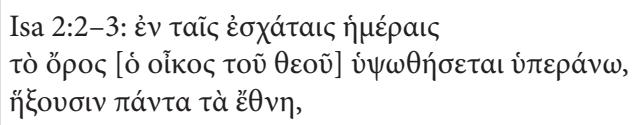 & 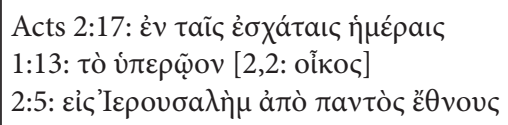 \\
\hline 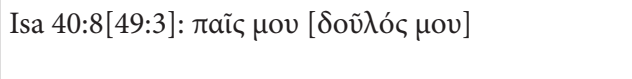 & 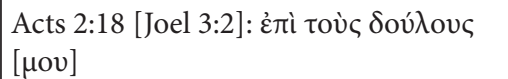 \\
\hline 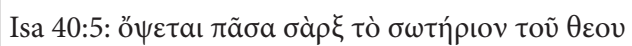 & 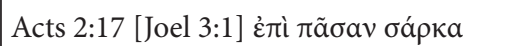 \\
\hline
\end{tabular}


In the subsequent narrative sequence, Acts 3-4 in a similar manner, Isaiah's whispering voice can be heard in the Acts in terms of: (1) Christology and (2) soteriology.

(1) Peter presents the kerygma, i.e., God's plan of salvation in Christ, by explaining Jesus' name. Linking it to other Christological titles such as: servant, holy, righteous, leader to life (Acts 3:13-15), Peter evokes the figure of the Isaianic Servant (cf. Isa 43-53). (Goulder 2000, 72-73)

(2) Moreover, by applying the OT motif "cornerstone" to Jesus in Acts 4:11, Peter stresses the universal and soteriological meaning of the name. ${ }^{2}$ The image evokes the "stone both a stumbling block as well as cornerstone" (cf. Ps 117:22; Isa $8: 14 ; 28: 16: \lambda i(\theta o \varsigma)$.

\subsection{Themes in the summaries}

A thematic comparison of the narrative accounts shows that, while the first summary contains all the themes, ${ }^{3}$ the other two elaborate only certain aspects. The theme of unity, positioned right at the beginning $(2,42)$, is a fundamental characteristic of the community which encapsulates as well as subordinates all the other themes that are presented in both the first and the other two summaries. (Roloff 2002, 123) The unity of the community is therefore expressed as (1) table-fellowship and (2) the communion of goods and is based on (3) the authority of the apostles and (4) prayer. At the same time this persuades the general public to react (5) either with fear or with favour. In any case, God shows his favour, as displayed by the fact that (6) the community grows constantly.

\subsection{Overview of the narrative structure of Acts 1:1-5:42}

Considering the composition of the Jerusalem narrative section (Acts 1:1-8:4), Luke has demonstrated his narrative artistry by knitting the work together and forming parallels or concentric structures. The descriptions of the Ascension (Lk 24:44-53; Acts 1:3-11) bind the Gospel and the Acts. (Betori 1981, 25-51)

2 Also, Mt 21:42; Mk 12:10-11; Lk 20:17; Rom 9:32-33; 1 Pt 2:6.

3 Themes: unity through: (1) table-fellowship and (2) sharing goods; (3) the apostles' authority in teaching, miracles and service; (4) prayer; (5) response in fear and favour; and (6) divine favour and growth. 
1:12-14: summary statement

$$
\begin{aligned}
& \text { 1:15-22: } \quad \text { narrative episode: speech-event } \\
& \text { 2:1-41: } \quad \text { narrative episode: event-speech } \\
& \text { 2:42-47: first summary account }
\end{aligned}
$$

4:4: summary statement

$$
\begin{array}{ll}
\text { 3:1-26: } & \text { event-speech } \\
\text { 4:1-30: } & \text { event-speech }
\end{array}
$$

4:31: summary statement

\section{4:32-35: second summary account}

4:35-5:11: $\quad$ narrative episode

5:12-16: third summary account

$$
\text { 5:17-42: } \quad \text { narrative episode }
$$

\section{5:42: summary statement}

The summary statements $(1: 12-14 ; 4: 4.31 ; 5: 42)$ bind the section together, representing both a narrative grid as well as a narrative echo for the summary narrative accounts. While the first two summary narrative accounts $(2: 42-47$; $4: 32-35)$ are set in the sequence of the event-speech $(1: 15-2: 41 ; 3: 1-4: 31)$ pattern and indicate the formation of the new, divinely-formed authority of the apostles in the context of growing conflict with the religious authorities, the third summary underscores the apostles' authority, preparing the next stage of the conflict, which culminates with Stephen's death and the dispersion of the believers (8:4).

\subsection{Delimitation}

The summary is demarcated from the surrounding text based on the stylistic and

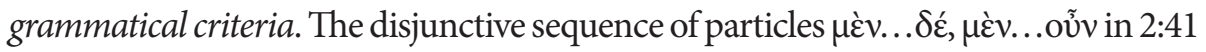
forms an overturning line, ${ }^{4}$ i.e., it concludes-summarizes what precedes, while preparing for a new sequence. (Cerfaux 1936, 673) The particle $\delta \dot{\varepsilon}$ in 2:42 indicates the transition to a new episode, ${ }^{5}$ not, however, without correlation with the previous one. (Zimmermann 1961, 76) The verbal tense used hints at the transition to a new episode, since in v. 2:41 Peter's speech concludes in the aorist tense ('£ $\beta a \pi \tau i ́ \sigma \theta \eta \sigma \alpha v$;

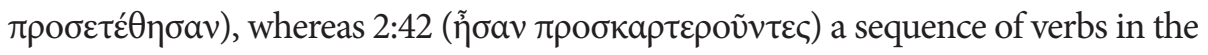

\footnotetext{
4 BDR $\$ \$ 447.451$.

5 The particle $\delta \dot{\varepsilon}$ either links (2:43.44) or disjoins the narrative (3:1).
} 
imperfect tense begins ${ }^{6}$ that continues until the aorist in $3: 4 .{ }^{7}$ However, a new episodes begins in 3:1, marked both by the emergence of the disjointing particle $\delta \dot{\varepsilon}$ as well as by the shift from the group-character (i.e., the community of the believers guided the apostles as presented through the summary 2:41-47) to the description of Peter and John going to the temple.

\section{Close reading: Point of View Analysis}

The narrator introduces his perspective in relation to the community of believers that represents the focused subject of the first narrative account. The subject

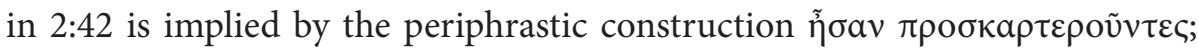
however, it is identified with the people who accepted Peter's words (2:41: oi

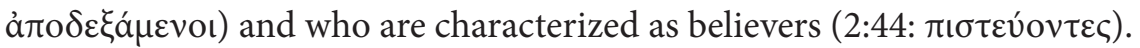

\subsection{Perceptual facet}

The perceptual facet, which focusses on time and space, remains vague yet eloquent. Temporal collocations are general, implying enduring or repetitive ac-

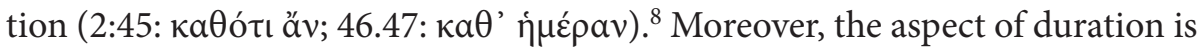
stressed by a sequence of verbs in the imperfect tense ${ }^{9}$ and the use of periphrastic constructions, ${ }^{10}$ or present participles. ${ }^{11}$

With reference to the spatial plane, a general adverbial formulation with

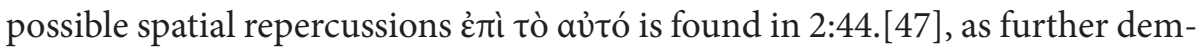
onstrated at the beginning of the Pentecost narrative sequence (2:1: being to-

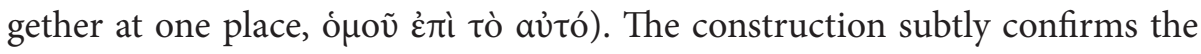

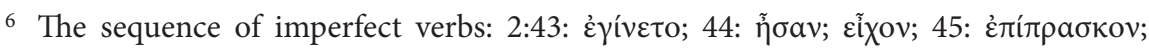

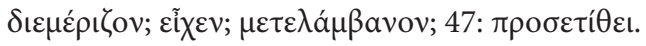

7 The sequence of imperfect tense describes the encounter of Peter and John with the

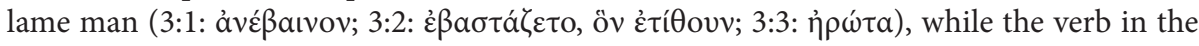

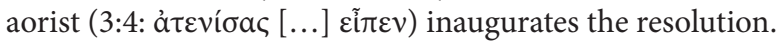

8 For the iterative construction $\kappa a \theta$ ó $\tau$ ı ăv + imperf. ind., see BDR $\$ 367.3$.

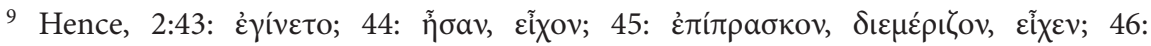
$\mu \varepsilon \tau \varepsilon \lambda a ́ \mu \beta a v o v$.

10 Periphrastic construction reflects a Semitic style (wayehi + participle).

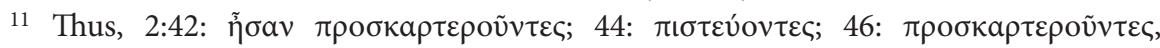

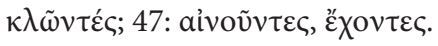


unanimity of the community formed by prayer, as indicated right from the beginning (1:14: ó $\mu \circ \theta v \mu a \delta o ̀ v ~ \tau \tilde{n} \pi \rho o \sigma \varepsilon v x \tilde{\eta})$. This portrayal of unity evokes Isaiah's demonstration of eschatological harmony (Isa 11:6: [יחדו]; 65:25: [כאחד] ä $\mu \alpha)$.

In addition, two more specific localisations are expressed: (1) a "house,"

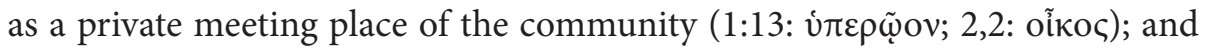
(2) the "temple," which implies a public dimension and thus prepares for the

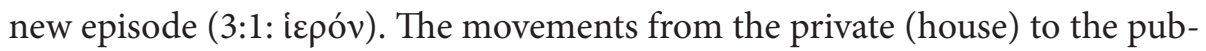
lic (temple) dimension expresses the vitality and openness of the community which remains under divine guidance (2:47). The tension between temple/ house is not merely aesthetic, but rather ideological. While the "temple" reference occurs here for the first time (2:46), it emerges several times in the first part of the book in relation to prayer and public teaching (3:1; 5:20.ff.; as Solomon's portico: $3: 11$; 5:12). ${ }^{12}$ Conversely, the reference to "house" is significant for the community's gatherings and prayer $(1: 13-14 ; 2: 1 ; 4: 23-31)$, the breaking of bread (2:46) and announcing the Good News (5:42). (Talgam 2013, 227-229) Luke, as Daniel Marguerat $(2003,306)$ underlines, composes his two-volume work around these two socio-religious terms. Luke's gospel is framed by the motif of temple; at the inaugural scene of Zechariah at the temple service; in the final scenes of the Gospel, the temple veil is torn in the middle at Jesus' death and after Jesus' ascension, the apostles remain praying in the temple (Lk 1:9; $23: 45 ; 24: 53)$. On the other hand, Acts begins with Jesus sharing a meal with his disciples (Acts 1:4) and concludes with Paul's house imprisonment (28:30-31). The motif of temple is re-evaluated: sanctuary is located in the Gentile world (19:24) or replaced by the motif of temple compound (i.e., as a place of teaching and prayer: $\operatorname{Lk} 22: 52-53 ; 24: 53$; as a place of pilgrimage: $\mathrm{Lk} 2$; as a place of the Sanhedrin: Acts $4-5$ ) or by the motif of house of God (Lk 6:5; 19,46; Acts 7:49). The juxtaposition of private-public/ house-temple hints at the program of restoration (cf. 1,8), that emerges in Isaiah. While the technical term vaós appears only in Isa 66:6, as God vindicates the city, the "house of the Lord" appears more often, however, it does not mean a "residence", since God abides in heaven $(63: 15 ; 66: 1-2)$ and in a humble heart $(57: 17)$, but rather it designates "place of prayer and gathering for all" (56:6-7; 60:7; 66:20). Luke’s tension

12 After the Stephen episode (6:8-7:60) the temple-institution seems to have lost meaning for the community (at least narratively), yet it reappears upon Paul's arrival in Jerusalem $(21: 27 ; 22: 17 ; 24: 12.18 ; 26: 21)$. 
between temple and house seems to be an inheritance of Isaianic anti-temple prophetic tradition.

\subsection{Psychological facet}

Here, the consideration of both the emotional and phraseological planes uncovers the dynamics of bringing about unity in the community and depends on both the divine and human dimensions. Here I will discuss four themes that for me, at least to some extent, remain an open question: (a) fear and joy; (b) table-fellowship; (c) preserving unity; and (d) sympathy.

\section{(a) Between fear and joy}

The emotional plane is first uncovered and strongly stressed through the internal focalizing 13 on "each person" who sees the wonders and signs of the

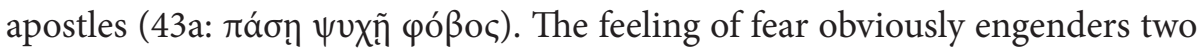
different responses: (1) some people join the Christians and (2) others are hesitant. This distinction foreshadows the subsequent events (cf. 5:11).

(1) The first part (2:43a) is not indicated through the usual verbal form

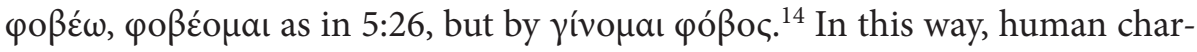
acter seems passively subdued when a "sense of awe comes upon him" in the face of special events. This feeling of respect arises "within each/every person" i.e., those who joined the community $(2: 41 \mathrm{~b}) .{ }^{15}$ The reverent fear and awe before the prophetic authority of the apostles permeates the new believers or even "surrounding non-Christians," as Haenchen (1968, 191-192) affirms. To this same effect, we can include the longer reading of some early textual witnesses

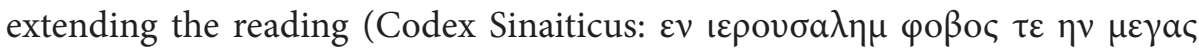

13 The narrator employs both external (by describing the believers: $2: 42.44-47$; and the people: $2: 46-47$ ) and internal focalization (by recounting emotions of believers: 2:43a.46; people: $2: 43$ c.46).

14 The formulation though rare in the OT (Gen 35:5; Exod 20:20; 2Chr 19:7) refers to a feeling of reverence when witnessing a divine intervention. The examples in Acts 5:5.11 link this awe with the formation of the assembly Church.

15 Instead of a more classical formulation yívoua + gen., the more Semitic formulation

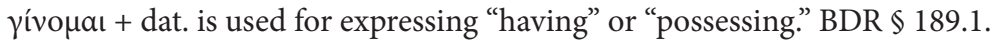


$\varepsilon \pi \mathrm{\imath} \pi \alpha v \tau \alpha \varsigma) .{ }^{16}$ In this manner, the feeling of awe is related to two distinctive

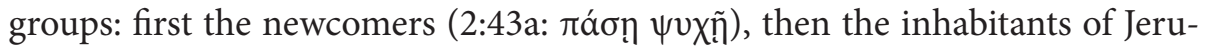

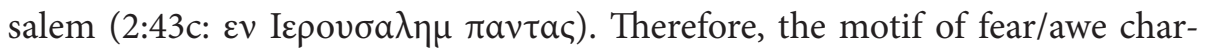
acterizes both the believers (2:43a) and the inhabitants of Jerusalem (2:43c), foreshadowing the pattern in 5:11.

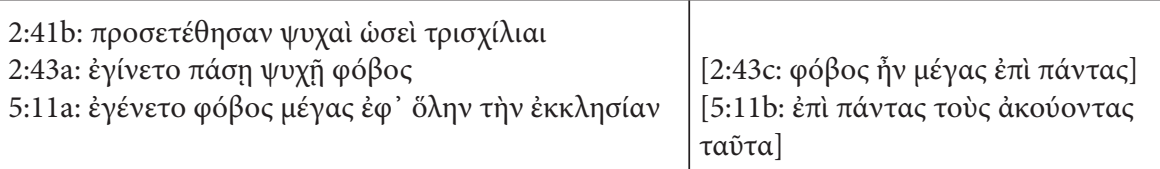

The initial awe (2:43) will be transformed into joy (2:46), as sharing meals is qualified with gladness/joy and singleness/simplicity of heart (2:46c). The se-

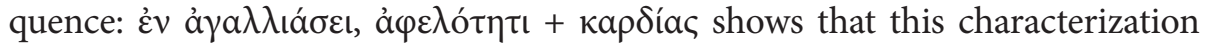
permeates the centre of a human being, his entire personality, his heart. In this particular case, joy and simplicity characterize a group of believers (2:44), who by accepting Peter's words (2:41) receive the Spirit and salvation (2:38.40.47). Thus, Max Turner $(1996,415)$ may affirm that "at least some of the exultation and praise of 2:46-47 resulted from a variety of levels of inspiration of the Spirit."

The joy of divine presence and salvific intervention nuances the sharing of meals. As a foretaste of eschatological commensality, the community is invited to re-establish and unify its relationships in simplicity and generosity (Wendel 1998, 235-244; Weiser 1990, 180). Simplicity as sincerity (Lk 11:34: $\dot{\alpha} \pi \lambda$ oṽ $)$,

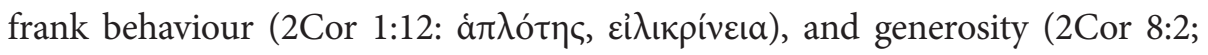

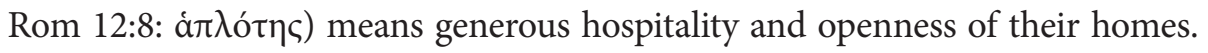
(Reicke 1957, 61) The community gathers to eat together not only to "satisfy its need for nourishment," but to "enjoy one another's company," as Andy Chambers $(2012,77)$ observes, and this enacts the message of the kingdom of God (Lk 10:1-9) and its inclusive hospitality (14:12-14). Sharing meals with joy and simplicity does not mean a reversal of social order but is rather the expression of a humble attitude in serving (22:26) and trust in God (12:29-34). This manner of life in unity requires a conscious decision and the acceptance of God's rule (Acts $2: 41-42)$ that is portrayed by the juxtaposition of fear and joy-simplicity. This

16 The text of NA27 is extant in: B, D, in 33 and $1739, \mathrm{M}$, gig, $\mathrm{p}^{*} \mathrm{r}$, Syh, sa. The long-

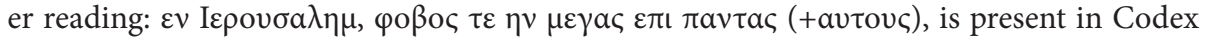
$\psi$ and a few manuscripts. 
pattern, which marks the renewed community, evokes the Isaianic NE. The fear as "terror" stems from the opposition to the Lord, causing a reaction of hiding (Isa 2,10), fleeing away at God's arrival and his judgment (Isa 24:17-18), however, it means also reverential respect as a gift of the Spirit to the Messianic king (11:3). Joy, on the other hand, is a response to God's salvation and the restoration of the people $(35: 10 ; 65: 14)$. Both fear as well as joy describe the people who experience God's action of salvation (51:9-12).

\section{(b) Forming table-fellowship unity}

Four elements in verse 2:42, describing the devotion and life of the community through the participle $\pi \rho о \sigma \kappa \alpha \rho \tau \varepsilon \rho \tilde{v} \nu \tau \varepsilon \varsigma$, are made explicit in the summary text: the role of the apostles (2:43); fellowship in terms of sharing goods (2:44-45); the breaking of bread (2:46); prayer life (2:47). (Johnson 1992, 61) Scholars arrange the elements of verse 2:42 in different ways due to textual-critical problems caused by the lack of the conjunction kai. The placing of the elements is revealing and intentional and calls for more attentive reading to under-

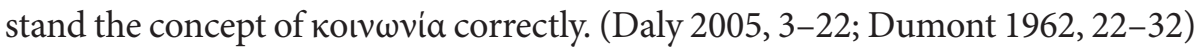

I would like to assess (1) the meaning of the term koเvwvia and (2) the division of the four elements.

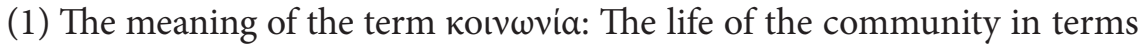
of fellowship has challenged scholars to produce numerous historical (Vermes 2013, 75), socio-rhetorical (Bartchy 1991, 313-317; Mitchell 1992, 258; Capper 1995, 324-356) and socio-apologetic interpretations (Sterling 1994, 679-696). Although the term on its own is used by Hellenistic authors who apply the philosophic or utopic concept of friendship for socio-political associations or factions (Malina and Pilch 2008, 36 ), the meaning cannot be limited to a mere sense of sharing goods. The correct understanding of the term must combine both its (a) historical and (b) theological implications.

(a) The historicity of the community's reciprocal care and sharing (2:44-45), in terms of organised collections, is literally attested both for the early

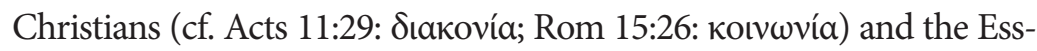
enes (1QS 1-2; 6:4-6; CD 1:10-11; 13:14-15). (Jeremias 1989, 211-214)

(b) On the other hand, the occurrences of the term kotvwvía in the NT suggest more intimate relationships in both spiritual (Phl 3:10; 1John 1:3) and sacramental (1Cor 10:16) terms. Therefore, this association in 
cultic rituals forms a new kinship group in terms of extended family, i.e., a family in faith. (Carr 1913, 461; Stein 2008, 27-95)

Such semantic range, from the concrete sharing of material goods to intimate communion, requires a specification of the term through correlation with three other descriptive elements in 2:42, which seem to be thoughtfully knitted together and interpret one another. (Wendel 1998, 187) Thus, Douglas Hume $(2011,100)$ relates fellowship to the "threefold commitment to relationships" of the new believers, i.e., "to the apostles and the other disciples, to one another and most importantly to God."

(2) The division of the four elements: As the semantic range is wide, two pairs of correlations will be proposed in order to combine the four elements that determine the community.

(a) teaching-fellowship / / breaking bread-prayer

(b) A: teaching/ / B: fellowship - B': breaking bread/ / A': prayer

(a) The omission of the conjunction creates a clear separation of two thematically distinct pairs. Whereas the first pair is related with a more cognitivedeliberative dimension (Bori 1972, 100-102), the second hints at a more spiritual-sacramental dimension. Charles Barrett (1994, 163-165) interprets the fellowship as "charitable use of its material resources," that is, an expression of the "common acceptance of the apostolic message." Robert Tannehill (1990, 148-149), points to the narrative pattern of teaching-fellowship echoed in the long-standing missionary activity of Barnabas and Saul in the Church of Antioch (Acts 11:26). Consequently, fellowship designates the sharing of personal belongings as "service," "aid," and "collection" for brothers in need (11:29).

(b) Conversely, the omission could be a sign of the deliberate intention to interpret the inner elements together, avoiding, however, the Eucharistic interpretation as expressed by the $\mathrm{vg}$ (communicatione fractionis panis) that would be anachronistic. Therefore, I agree with Bo Ivar Reicke's (1957, 57) chiastic arrangement, according to which the outer elements referring to a liturgical life entail practical consequences expressed by the inner elements. Following his insight to elucidate the crux interpretum represented by the notion of "fellowship," two inner elements (B: fellowship, B': breaking of bread) are brought close together, albeit not in appositional but in 
complementary terms. This correlation of terms permits the interpretation of fellowship as table-fellowship, opening the question of Christian liturgical development. Whether the correlation between fellowship and mealsharing corresponds to the sequence of primitive Christian liturgy (Jeremias 1966, 120-121) or is simply an overlap of the two concepts in Luke's time remains historically unclear. ${ }^{17}$ Nevertheless, the foregoing concept of table-fellowship, i.e., sharing meals and belongings, is clearly based on the memory of Jesus' breaking bread (cf. Lk 5:27-39), sharing meals, as well as evoking the Lord's Supper (cf. 22:19) and the presence of the Risen Lord (Lk 24:30; Acts 1:3-4). Therefore, the table-fellowship goes beyond human fellowship, as Tannehill $(1986,290)$ says, "to include communion with the risen Lord."

Consequently, fellowship is not based on some ethical-ideological decision (Reicke 1957, 60), ${ }^{18}$ but rather is motivated by intimate brotherly communion in Christ (cf. 2:38). Just as Jesus' breaking of bread calls for the reversal of social roles (cf. Lk 22:25-27), ${ }^{19}$ so the life of the community also demands "commitment to His people" (Chambers 2012, 68) and kinshiplike relationships and inclusive openness that break the limits of ritual purity vis-à-vis the Gentiles (cf. Acts 10:15). In this sense, table-fellowship as generous hospitality in sharing goods and meals (2:44-46) means "sharing in each other's lives," as Chambers $(2012,74)$ affirms. Thus, table-fellowship, in its merging of sacred and common, evokes the Isaianic reformulation of the Jubilee (cf. Isa 33:15-16; 58:6-12). This is based on hope of the eschatological banquet prepared by the Lord (25:6-10).

17 The occurrences in Acts refer to liturgy $(2: 42 ; 20: 7.11)$ and the common meal (2:46; 27:35). Heinrich Kahlefeld (1980, 30-40) argues that the title "breaking of bread" implies a connection between the sacramental Eucharist and the profane sharing of meals (Lovefeast, Agape; cf. Jude 1:12; 2Pt 2:13; Ign. Smyrn. 7:1; Tertullian, Apol. 39:10-19). The distinction was introduced in the third century by the Apostolic Tradition attributed to Hippolytus of Rome.

18 Relativizing possession forms a community of "poor," i.e., those who trust in the Lord (cf. Ps 9:19; Isa 58:7; Rom 15:26).

19 The terminology of breaking of bread links to Jesus' practice (Lk 22:19; 24:35; Acts

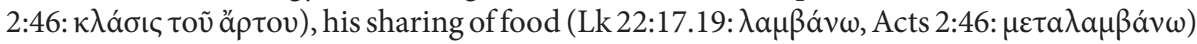
and his interpretation of table-fellowship (cf. Lk 14:12-15). 


\section{(c) Preserving unity}

Returning to the external elements in 2:42 (A: teaching of the apostles, A': prayers), these seem to guarantee the formation of unity, and they later define a specific service of the apostles (cf. 6:4). Up to this point, only Peter seems to exercise the role of teaching, albeit a role granted to all the apostles (Lk 22:9-30; Acts 1:22). The summary applies this role to all the apostles. The teaching is enhanced by miraculous deeds (2:43b) that relate the apostles with Jesus (2:22) as the fulfilment of the prophetic role (2:19) (Wolterstorff 1995, 37-57; Malina and Pilch 2008, $35-36$ ) with the purpose of giving guidance to the people (Exod 11:9; Isa 20:3). ${ }^{20}$

The apostles exercise the judgement of the twelve tribes through:

(1) teaching and social care (Acts 2:42: cf. Lk 22:30; Isa 50:4ff); and

(2) working miracles like Jesus (Lk 7:22; Acts 2:22), as a sign of divine intervention for his people (cf. Exod 7:9; Isa 37:30-32). They enact Jesus' reunification of Israel (Lk 2:30-32; cf. Isa 11:13; 49:6).

The reference to prayer, on the other hand, maintains the eschatological character of the community in so far as it already exists and is still to be realized. Therefore, prayer enables progress (Acts $1: 24 ; 6: 6$ ) and perseverance in times of trial (1:7; 4:24ff.). (Plymale 1991, 84-88) Prayer and teaching point to the primacy of God and his agent of salvation Jesus Christ (cf. 2:32-33). (Weiser $1990,182-183)$ Both prayer and teaching are expected to be located in the temple, which in Jesus' words is a house of prayer (Lk 19:46 [Isa 56:7]) (Holmås $2011,177)$ and the place of Jesus' teaching (Lk 19:47; 21:37). ${ }^{21}$ Yet, there is a shift. Whereas at the end of the Gospel the apostles remain praying in the temple (Lk 24:52-53), in Acts the theme of prayer seems to be related to the upper room ${ }^{22}$ of a house (Acts 1:12-14). (Wendel 1998, 170-180; Sleeman 2009, 83-84)

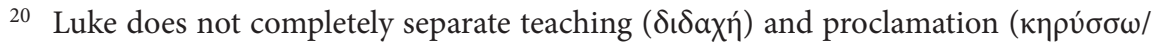
$\kappa \eta ́ \rho v \gamma \mu \alpha)$. Teaching referring to Christ (Acts 13:12) addresses both the community and outsiders $(2: 46 ; 5: 28)$. Proclamation indicates the prophetic role of the prophets such as Jonah, Jesus, and the apostles (Lk 4:18; 11:32; 24:47). Acts links this prophetic role with the proclamation of Christ (Acts 8:5; 9:20).

21 While in Jerusalem, Jesus teaches in the temple (Lk 19:47; 20:1.21;21:37); otherwise, he teaches in synagogues $(4: 15.31 ; 6: 6 ; 13: 10)$, in cities $(13: 2.26)$, from a boat $(5: 3)$, and in a house (5:17).

22 The term is not directly related to Jesus' Last Supper or Eucharist (Lk 22:12: ảvá yaııv $\mu \varepsilon \dot{\gamma} \alpha$ ), yet it indicates the site of resurrection and restoration to fellowship (cf. Acts 1:13; 9:37; 20:8). 
The spatial tension between house (private) and temple (public) is present in the summary (2:46). ${ }^{23}$ This tension is emphasised by the reference to teaching. (Neyrey 2003, 72-102) While Peter teaches in a house in the first two chapters of Acts $(1: 15 ; 2: 1)$, in the later section, which sees growing conflict with the temple authorities (Acts 3-5), the temple becomes the place of teaching $(3: 11 ; 5: 12)$ and is sanctioned by divine ordinance (5:20.21.25.42). The juxtaposition of temple and house in 2:46 sets the community in continuity with Israelite tradition, while indicating a newness (Turner 1979, 114-130; Beale 2005, 201-208; Wardle 2010, 191-206;) in the openness of homes as a starting point for the universal mission. (Matson 1996, 47-52; Dunn 1996, 36)

\section{(d) Enjoying sympathy}

The formulation $\chi^{\prime} \chi \omega \chi \chi \alpha ́ \rho เ v+\pi \rho o ́ \varsigma ~(2: 47)$ is somewhat problematic for two simple reasons: (1) there is little resonance in the NT (cf. Lk 17:9; Heb 12:28:

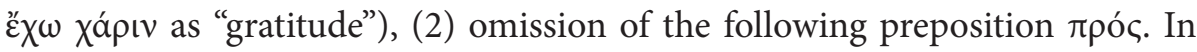
order to understand the meaning of the formulation one has to include two additional points. First, the value of the preposition "having favour" in terms of (1) direction ${ }^{24}$ "to, toward, unto;" or (2) position ${ }^{25}$ "at, beside." Secondly, other cognate formulations express "favour." While in the OT the instances express: "finding favour with," ${ }^{6}$ "enjoying favour,"27 and "showing favour,"28 in the Lukan corpus the term refers mostly to the static experience of divine favourgrace (Lk 1:30; 2:40 cf. Acts 4:33; 7:46; 11:23). Given the fact that Luke uses other means to express the active showing of favour (Acts 7:10;25:9), the static value is to be preferred: the community thus experiences favour in sight of,

23 The terms oĩkoc/íepóv convey private/public opposition (2:46; 5:42).

24 The preposition has directional meaning with the verbs of communication (to speak, tell: Lk 1:8; Acts 2:37) and movement (going, coming: Lk 7:4; Acts 9:2).

25 The static meaning fits with more static verbs "to stay, to sit, to bring" (at the feet: Lk 10:39; Acts 4:37; at the doors: Lk 16:20; Acts 3:2).

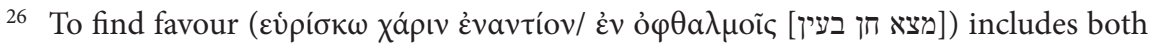

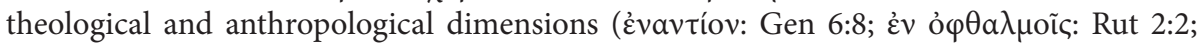
1Sam 1:18; 1Esd 6:5).

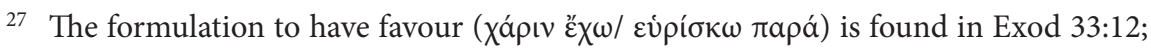
Est 2:9.

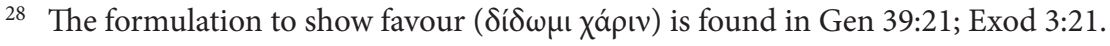


or among, the people. ${ }^{29}$ The formulation "enjoying favour with all the people" (2:47) does not designate only a crowd, but implies the theological notion of the people of God. ${ }^{30}$ In fact, the ingathering of the Diaspora Jews at the Pentecost (2:5) as "the whole house of Israel" (2:36) hints at the inauguration of the restoration process (cf. 1:8). Here we can evoke Isaiah as he depicts the sympathy of the Lord towards Israel (Isa 11:11; 50:4). In brief, sympathy for the nascent community, implies its special place in the restoration of God's people.

\subsection{Ideological facet}

The narrator expresses his world-view through a narrative frame that serves as an interpretative aid for understanding the story. The ideological facet displayed below singles out theme of unity in terms of (1) unity-restoration, (2) table-fellowship, and (3) prayer representing the basis for the life of the community and evoking the Isaianic NE.

(1) First of all, the community is characterized by unity (2:44.46[47]) representing a realization of the initial hopes of restoration (cf. Acts 1:6). However, those members who do not respect this unity are opposing the community's divine Creator (cf. 5:4.9) and are doomed (1:25[5:5.10]). Apart from the historical plausibility undergirded by the Qumran community (1QS 8:2), the notion of unity emerges in Isaiah displaying both negative (Isa 41:1) and positive traits (11:6; 65:25). (Pouilly 1976, 87)

If unity becomes a characterizing trait of the community (2:47: kúpıoৎ

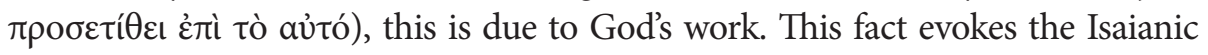
process of restoration, primarily ascribed to the Lord by showing his arm on be-

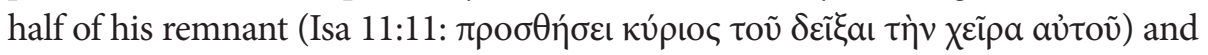

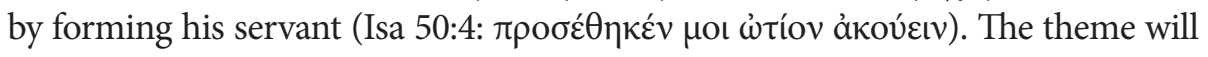

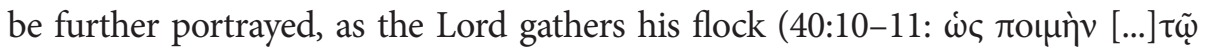

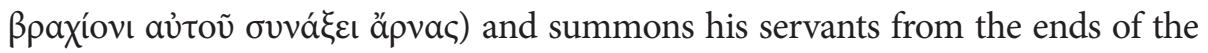

29 Haenchen $(1971,193)$ binds together $2: 46-47$, so that the praise of God arises from experience of God's loving-kindness (cf. Lk 2:13; Acts 3:8). Conversely, Wendel (1998, 245-246) defends the directional value, since the community offers meals of salvation to the people.

30 The term has the theological sense of people of God: Lk $1: 10.17 .68 .77 ; 2: 10 ; 31-32$ : $7: 16.29 ; 18: 43 ; 20: 1 ; 21: 38 ; 22: 2 ; 23: 5 ; 24: 19$; Acts $3: 12.23 ; 4: 2 ; 5: 12-13 ; 6: 8$. 
earth (41:8-9) and redeems his people (43:1-9). ${ }^{31}$ To this end God makes use of his servant Israel (42:1-7), or even a foreign ruler like Cyrus (45:1-4). ${ }^{32}$

Moreover, in the summary an implication of restoration is further noticed in the spatial reference to Jerusalem/the temple (Acts 2:43.46). The Isaianic NE foresees the divine salvific intervention on Zion's behalf (Isa 51:9-12; 59:20-60,2); however, this plan has universal repercussions (60:3.5-14). Whereas in Isaiah the Gentiles are dominated by the Jews (cf. 49:7), in Acts the relationship between the Gentiles and the Jews is marked by equality before God (Acts 10:34). This new understanding is foreshadowed in this summary in Acts by the institution of the house/household, which enhances the possibility of overcoming social-religious boundaries (2:46). The change in pattern is portrayed in the episode of the cleansing of the temple (Lk 19:46) in two points: (1) Jesus' omission of "all the nations"

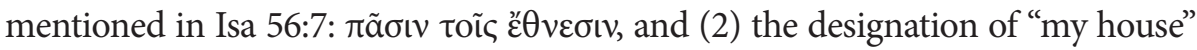

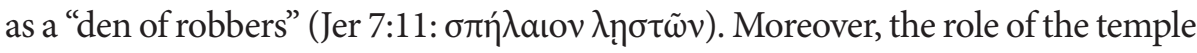
is later relativized in Stephen's speech (Acts 7:49-50; Isa 66:1-2). ${ }^{33}$ In short, the theme of unity and restoration corresponds to the Isaianic NE in terms of universal restoration.

(2) Table-fellowship as an expression of unity (2:42), enables kinfolk relationships among members, implying some form of common possession achieved by selling goods and distributing proceeds to the needy (2:45). However, the main focus is on unity based upon the communion with the Lord, as Alan Thompson $(2008,67)$ concludes:

The focus is not primarily on a 'community of goods' but on meeting needs as an expression of the unity of the community in common allegiance to the Lord Jesus.

Moreover, table-fellowship means sharing meals, which echoes the Isaianic NE in three ways: (1) by reinterpreting Jubilee tradition in terms of loosening

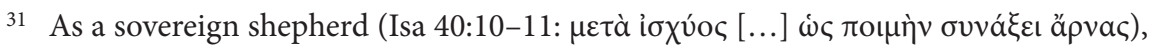

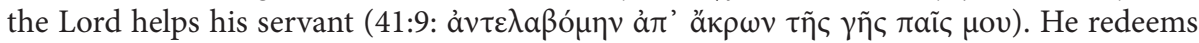
by urging his people to return from all parts of the earth (43:1: $\dot{\varepsilon} \lambda \nu \tau \rho \omega \sigma a ́ \mu \eta \nu ~[. .] ~ 43:$.5 :

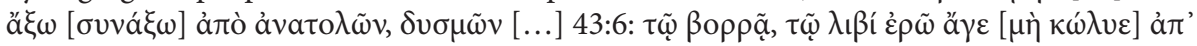

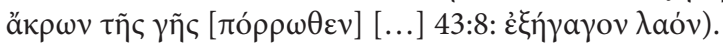

32 Cyrus is the Lord's anointed (Isa 45:1) urged to fulfil God's will in rebuilding Jerusalem and the temple (44:28), all for the purpose of Israel and the world (45:4-6).

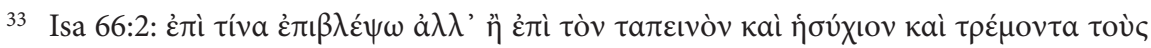

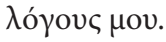


the chains of injustice, sharing bread and house with the outcast (58:6-7), and (2) by realising eschatological hopes through the empowerment of the Spirit (61:1), and (3) by interpreting the welcoming of homes in universal terms (58:7). The prophetic role of the restoration of social justice, meal sharing with universal openness announced in the Nazareth episode (Lk 4:14-21), now passes over to the community (cf. Acts 2:38-39). Table-fellowship, as an expression of the social dimension of the restoration, thus evokes the third criterion of Isaianic NE. (Gurtner 2013, 140)

(3) The reference to prayer (Acts 2:42.47) characterizing the community implies the recognition of the primordial authority of God and the experience of

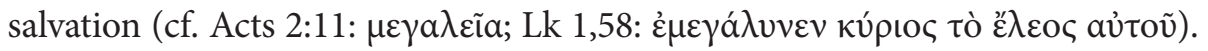
In Isaiah the Lord magnifies his praise by showing his faithfulness (Isa 42:21:

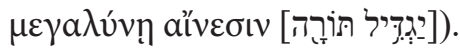

Moreover, prayer has the purpose of forming and preserving unity (cf. Acts 1:14ff.) especially in periods of trial (cf. 4:24ff.). The image of God who is both omniscient, i.e., knowing the hearts of man as well as mighty creator of heaven and earth evokes the theme of prayer in Isaiah. God knows about the Assyrian treatment of Jerusalem and promises a comfort to the people (Isa 37:6: $\mu$ 门

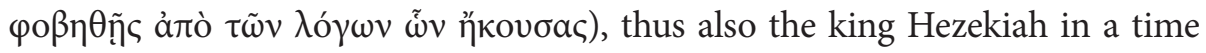

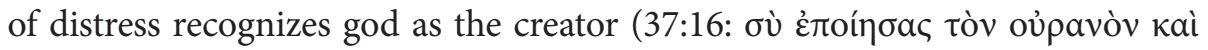
$\tau \grave{\eta} v \gamma \tilde{\eta} v)$. This relationship with the Lord is encapsulated by the tongue of disciples during the time of trial (cf. 50:4-5). Later Hezekiah utters another prayer of gratitude for salvation with expressions of praise and joy (38:18-19[19-20]:

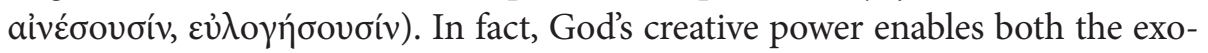
dus of the redeemed people and its joyful response (cf. 51:9-11). ${ }^{34}$

\section{Synthesis}

The first summary concludes the section describing the formation of the community (Acts 1:12-2,47). The summary, despite being a distinct narrative unit beginning with the transitional verse 2:41, represents a corollary of Pentecost. The Spirit empowers believers for the role of God's servants living the prom-

34 The terminology used in the context is clearly related to redemption (Isa 51:10:

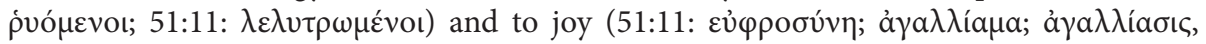

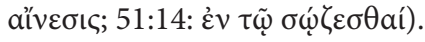


ised divine blessing. However, the longer reading in 2:43 alludes to the sifting process of the restoration by referring to Jerusalem and its inhabitants. While Jerusalem represents the starting point of the restoration including both centripetal and centrifugal dimensions, the distinction between the believers and the inhabitants introduces a necessary form of restoration. Luke introduced psychological facets in order to persuade the reader to share his world view. The summary focuses on unity as the main characteristic of the community. The fellowship is intended as table-fellowship, i.e., commensality combined with the quasi-liturgical breaking of bread. The eschatological blessing, conditioned by social justice featured in Isaiah and fulfilled in Jesus' sharing of meals to overcome social/religious boundaries, is an invitation to the community to undergo moral and socio-religious conversion.

\section{Bibliography}

Bartchy, S. Scott. 1991. "Community of Goods in Acts. Idealization or Social Reality?" In The Future of Early Christianity. Essays in Honor of Helmut Koester, edited by Birger A. Pearson, Thomas A. Kraabel, George W.E. Nickelsburg and Norman R. Petersen, 309-318. Minneapolis MN: Fortress Press.

Beale, Gregory K. 2005. "Eden, the Temple, and the Church's Mission in the New Creation." Journal of the Evangelical Theological Society 48.1:5-31.

Betori, Giuseppe. 1981. Perseguitati a causa del Nome. Strutture dei racconti di persecuzione in Atti 1,12-8,4. Vol. 97, Analecta Biblica. Rome: Biblical Institute Press.

Bori, Pier Cesare. 1972. Koinônia. L'idea della comunione nellecclesiologia recente e nel Nuovo Testamento. Brescia: Paideia.

Capper, Brian J. 1995. "The Palestinian Cultural Context of Earliest Christian Community of Goods." In The Book of Acts in its Palestinian Setting edited by Richard Bauckham, 324-356. Grand Rapids MI: Eerdmans.

Carr, Arthur. 1913. "The Fellowship (Koıvwvıa) of Acts II. 42 and Cognate Words." The Expositor 8.5:458-464.

Cerfaux, Lucien. 1936. "La composition de la première partie du livre des Actes." Ephemerides Theologicae Lovanienses 13:667-691.

Chambers, Andy. 2012. Exemplary Life. A Theology of Church Life in Acts. Nashville (TN).

Daly, Robert J. 2005. "Eucharistic Origins: From the New Testament to the Liturgies of the Golden Age." Theological Studies 66:3-22.

Dumont, Enrique. 1962. "La koinonía en los primeros cinco capitulos de los hechos de los Apostoles." Revista biblica 24 (1):22-32.

Dunn, James D. G. 1996. The Acts of the Apostles, Epworth Commentaries. London: Epworth Press. 
Fitzmyer, Joseph A. 2003. Gli Atti degli Apostoli. Introduzione e commento. Brescia: Queriniana.

Goulder, Michael D. 2000. “The Anointed." In The Old Testament in the New Testament. Essays in Honour of J.L. North, edited by J. L. North and Steve Moyise, 66-74. Sheffield: Academic Press.

Gurtner, Daniel M. 2013. “Luke’s Isaianic Jubilee.” In From Creation to New Creation. Biblical Theology and Exegesis. Essays in Honor of G. K. Beale, edited by Daniel M. Gurtner, Benjamin L. Gladd and Gregory K. Beale, 123-146. Peabody MA: Hendrickson.

Haenchen, Ernst. 1971. The Acts of the Apostles. A Commentary. Oxford: Basil Blackwell. Haenchen, Ernst 1968. "The Book of Acts as Source material for the History of Early Christianity." In Studies in Luke-Acts. Essays presented in honor of Paul Schubert, edited by L. E. Keck and J. L. Martyn, 258-278. London.

Holmås, Geir Otto. 2011. Prayer and Vindication in Luke-Acts. The Theme of Prayer within the Context of the Legitimating and Edifying Objective of the Lukan Narrative. Vol. 433, Library of New Testament Studies. London: T \& T Clark.

Hume, Douglas A. 2011. The Early Christian Community. A Narrative Analysis of Acts 2:41-47 and 4:32-35. Vol. 2.298, Wissenschaftliche Untersuchungen zum Neuen Testament. Tübingen: Mohr Siebeck.

Jeremias, Joachim. 1966. The Eucharistic Words of Jesus. London: SCM.

Jeremias, Joachim. 1989. Gerusalemme al tempo di Gesù. Ricerche di storia economica e sociale per il periodo neotestamentario. Bologna: EDB.

Johnson, Luke Timothy. 1992. The Acts of the Apostles. Vol. 5, Sacra Pagina Series. Collegeville MN: The Liturgical Press.

Malina, Bruce J., and John J. Pilch. 2008. Social-Science Commentary on the Book of Acts. Minneapolis: Fortress Press.

Marguerat, Daniel. 2003. "Du Temple à la maison suivant Luc-Actes.0148” In Quelle maison pour Dieu?, edited by Camille Focant, 285-317. Paris: Éditions du Cerf.

Matson, David Lertis. 1996. Household Conversion Narratives in Acts. Pattern and Interpretation. Vol. 123, Journal for the Study of the New Testament Supplement. Sheffield: Academic Press.

McWhirter, Jocelyn. 2013. Rejected Prophets. Jesus and His Witnesses in Luke-Acts. Minneapolis MN: Fortress.

Mitchell, Alan C. 1992. "The Social Function of Friendship in Acts 2:44-47 and 4:32-37.” Journal of Biblical Literature 111 (2):255-272.

Neyrey, Jerome H. 2003. “»Teaching You in Public and from House to House« (Acts 20.20). Unpacking a Cultural Stereotype." Journal for the Study of the New Testament 26.1:69-102.

Pao, David W. 2000. Acts and the Isaianic New Exodus. Tübingen: Mohr Siebeck.

Plymale, Steven F. 1991. The Prayer Texts of Luke-Acts. Vol. VII. Theology and Religion. 118, American University Studies. New York: Lang.

Pouilly, Jean Ocso. 1976. La Règle de la Communauté de Qumrân. Son évolution Littéraire. Vol. 17, Cahiers de la Revue biblique. Paris: J. Gabalda. 
Reicke, Bo Ivar. 1957. Glaube und Leben der Urgemeinde. Bemerkungen zu Apg. 1-7. Zürich: Zwingli-verlag.

Roloff, Jörgen. 2002. Gli Atti degli Apostoli. Brescia: Paideia.

Sleeman, Matthew. 2009. Geography and the Ascension Narrative in Acts. Vol. 146, Society for the New Testament Studies Monograph Series. Cambridge: Cambridge University Press.

Stein, Hans Joachim. 2008. Frühchristliche Mahlfeiern. Ihre Gestalt und Bedeutung nach der neutestamentlichen Briefliteratur und der Johannesoffenbarung. Vol. 255, Wissenschaftliche Untersuchungen zum Neuen Testament. Tübingen: Mohr Siebeck.

Sterling, Gregory E. 1994. " "Athletes of Virtue». An Analysis of the Summaries in Acts (2:41-47; 4:32-35; 5:12-16)." Journal of Biblical Literature 113 (4):679-696.

Talgam, Rina. 2013. “The Representation of the Temple and Jerusalem in Jewish and Christian Houses of Prayer in the Holy Land in Late Antiquity." In Jews, Christians, and the Roman Empire. The Poetics of Power in Late Antiquity, edited by Natalie B. Dohrmann and Annette Yoshiko Reed. Philadelphia: University of Pennsylvania Press.

Tannehill, Robert C. 1986. The Narrative Unity of Luke-Acts. A Literary Interpretation. 1. The Gospel According to Luke. Philadelphia: Fortress Press.

Tannehill, Robert C. 1990. The Narrative Unity of Luke-Acts. A Literary Interpretation. 2. The Acts of the Apostles. Philadelphia: Fortress Press.

Thompson, J. Alan. 2008. One Lord, One People. The Unity of the Church in Acts in its Literary Setting. Vol. 359, Library of New Testament Studies. London: T \& T Clark.

Turner, Harold W. 1979. From Temple to Meeting House. The Phenomenology and Theology of Places of Worship. Vol. 016, Religion and Society. Paris: Mouton.

Turner, Max. 1996. Power from on High. The Spirit in Israel's Restoration and Witness in Luke-Acts. Sheffield: Academic Press.

Vermes, Geza. 2013. Christian Beginnings. From Nazareth to Nicaea, AD 30-325. London: Penguin.

Wardle, Timothy. 2010. The Jerusalem Temple and Early Christian Identity. Vol. 2.291, Wissenschaftliche Untersuchungen zum Neuen Testament. Tübingen: Mohr Siebeck.

Weiser, Alfons. 1990. Studien zu Christsein und Kirche. Stuttgart: Katholisches Bibelwerk. Wendel, Ulrich. 1998. Gemeinde in Kraft. Das Gemeindeverständnis in den Summarien der Apostelgeschichte. Vol. 20, Neukirchener theologische Dissertationen und Habilitationen. Neukirchen-Vluyn: Neukirchener Verlag.

Wolterstorff, Nicholas. 1995. Divine Discourse. Philosophical Reflections on the Claim that God Speaks. Cambridge: University Press.

Zimmermann, Heinrich. 1961. "Die Sammelberichte der Apostelgeschichte.” Biblische Zeitschrift 5:71-82. 